\title{
Investigating the Quality of Life on Farmer Family: Roles of Gender Relations, Economic Pressure, Financial Management, and Livelihood Strategies
}

\author{
Tin Herawati ${ }^{1}$, Megawati Simanjuntak ${ }^{2)^{*}}$, Berti Kumalasari ${ }^{3}$ \\ ${ }^{1,2}$ Department of Family and Consumer Sciences, Faculty of Human Ecology IPB University, \\ Bogor 16680, West Java, Indonesia \\ ${ }^{3}$ Indonesian Family Love Foundation, Bogor 16144, West Java, Indonesia \\ *) Corresponding author: mega_juntak@apps.ipb.ac.id
}

\begin{abstract}
Indonesia as the largest tropical agricultural countries support natural conditions make Indonesia a country rich in agricultural products. The objective of this research was to analyze the influence of economic pressures, financial management, gender relations, and livelihood strategies toward the farmer families quality of life. This research used a quantitative study design. The research took place in West Java. Sixty respondents were chosen from the farmer's wife that selected by using a simple random sampling. Data were collected directly using a structured questionnaire. Partial Least Square analyzed data. The results show that farmers' family economic pressure significantly affects livelihood strategy and quality of life, gender relations significantly affect livelihood strategy and financial management, and financial management significantly affects the quality of life. As suggestions, farmers families should further improve their livelihood strategies and financial management by understanding the importance of limited use of family resources. The implications for government are providing programs to improve quality of life, by forming cooperatives involving the role of farmers' wives.
\end{abstract}

Keywords: economic pressure, financial management, gender relations, livelihood strategies, quality of life

\begin{abstract}
Abstrak
Indonesia sebagai negara pertanian tropis terbesar mendukung kondisi alam yang menjadikan Indonesia negara yang kaya akan hasil pertanian. Tujuan penelitian ini adalah untuk menganalisis pengaruh tekanan ekonomi, pengelolaan keuangan, relasi gender, dan strategi penghidupan terhadap kualitas hidup keluarga petani. Penelitian ini menggunakan desain penelitian kuantitatif. Penelitian berlangsung di Jawa Barat. Enam puluh responden dipilih dari istri petani yang dipilih secara acak sederhana. Pengumpulan data dilakukan dengan wawancara. Data dianalisis dengan Partial Least Square. Hasil penelitian menunjukkan bahwa tekanan ekonomi keluarga petani berpengaruh secara signifikan terhadap strategi penghidupan dan kualitas hidup, hubungan gender berpengaruh signifikan terhadap strategi penghidupan dan manajemen keuangan, dan manajemen keuangan secara signifikan mempengaruhi kualitas hidup. Sebagai saran, keluarga petani sebaiknya lebih meningkatkan strategi penghidupan dan pengelolaan keuangan dengan memahami pentingnya keterbatasan penggunaan sumber daya keluarga. Implikasinya bagi pemerintah adalah memberikan program peningkatan kualitas hidup, dengan membentuk koperasi yang melibatkan peran istri petani.
\end{abstract}

Kata kunci: kualitas hidup, manajemen keuangan, relasi gender, strategi nafkah, tekanan ekonomi 


\section{Introduction}

Indonesia is one of the largest tropical agricultural countries in the world which has abundant biodiversity. Supporting natural conditions makes Indonesia a country rich in agricultural products (Basrowi \& Juariyah, 2010). People's livelihoods in the agricultural sector in Indonesia are generally lowland rice farmers (Sunarti \& Sumarno, 2011). Lowland rice farmers, namely those who work in the fields and produce rice with the status of private ownership or workers on land owned by others (Azalia, 2015). The results of the analysis of the characteristics of farmers' businesses show that food crop farmers dominate agricultural households, the average per capita income based on business in the pure rural sector as a result of the 2013 Agricultural Census is below the poverty line. Although the education level of farmers is still very low, namely not completing elementary school (38\%) and completing elementary school (33-42\%), agricultural households that do not have health insurance are classified as high, namely 53.96 per cent (Sabarella et al., 2014).

The BPS census data in 2016(a) stated that as many as 5.50 million Indonesians aged 15 years and over according to their main employment status were agricultural households, most of the workers in the agricultural sector lived below the poverty line. Poverty shows the inability of the family to respond and adapt to the environment, this causes the family to experience economic pressure (Sunarti, Kholifah, Vidiastuti, Kharisma, Rochimah, \& Herawati, 2013). Economic pressure will encourage families to improve financial management and other livelihood strategies. This becomes an important thing so that the family can survive in maintaining the continuity and sustainability of life (Sunarti, Tati, Atat, Noorhaisma, \& Lembayung, 2005; Fofana, 2009). Financial management is the science or practice of managing money or other assets (Goldsmith, 2010).

Financial management is a series of tasks that focus on financial resources to ensure the availability of funds to meet the wife's daily needs (Garman \& Forgue, 2000). According to Van-Raaij, Antonides, and De Groot (2020), the level of education and the type of wife's working affect the skills of wives in financial management. The higher the level of education and the type of wife's work will be the better the family financial management. In this case, gender relations must work well, especially in terms of decision making. Other resources in the family can be managed by the family through livelihood strategies to improve the quality of life (Frankenberger, Luther, Becht, \& Katherine, 2002; Puspitawati, 2012). Unfulfilled basic life needs encourage wives to try to meet these shortcomings by working, this makes wives have dual roles, namely roles in the domestic and public sectors. A wife involved in fulfilling family needs is a livelihood strategy that utilizes human capital in the family. The livelihood strategy has a significant positive relationship with gender relations. Increasing the livelihood strategy in the family improves gender relations, which aims to maintain a harmonious relationship between husband and wife (Nugraheni, 2012; Puspitawati, 2015). Livelihood strategy is the ability, assets, and resources to meet basic living needs (Chambers \& Conway, 1991). Fofana (2009) states that the livelihood strategy can improve the family's objective and subjective quality of life.

Poverty as a problem that caused of inability to meets economic needs experienced by 10.64 per cent Indonesian people who majorities is farmer family. West Java province as the larger population in Indonesia have 8.77 per cent poor people, while Subang as the district which have 11.73 per cent poor people (BPS, 2014; 2016). 
Based on the BPS poverty line, the proportion of agricultural households in the poor category is 23.46 per cent. The factors that influence poverty in families are low education, difficulty finding other jobs, very low income, lack of capital, and weak mastery of management and technology aspects (Husin, 2009; Soesilo, 2007). The problems faced by the family require its members to be able to solve them effectively. Families can do various things to deal with and minimize various risks such as economic pressures, including financial management so that income does not just run out and can be used when needed and a double income strategy to maintain and increase assets, resources, and abilities for the next generation. Also, this is an effort to improve the quality of family life (Chambers \& Conway, 1991; Okech, 2012; Rodhiyah, 2012).

The theoretical approach used in this research is functional structural which recognizes the great diversity in social life. This diversity is part of the structure of society which in the end emerges diversity in functions according to one's position in the structure of a system (Megawangi, 2014). In addition, gender theory is also used as the basis for this research. According to Puspitawati (2012), gender discusses the problems of women and men in social life. Gender relations are relations between men and women related to the division of roles carried out in various types and family structures. This study differs from previous studies by focusing on farming families and looking at the quality of life based on objective and subjective. Therefore, this study aims to analyze the influence of gender relations, economic pressures, family financial management, and livelihood strategies on the quality of life of farmer families.

\section{Methods}

\section{Participants}

This study used a quantitative approach and data collection using a survey method in Legonkulon Village, Legonkulon District, Subang Regency, and West Java. The research location was chosen based on the livelihood of the dominant farmer population, The other reasons are with the consideration that the area has unique demographic characteristics, with agricultural and coastal land located in one subdistrict area.

The population of this research is family farmers who live in Legonkulon Village, Legonkulon District, Subang Regency, West Java. Respondents in this study were wives from farming families. The sampling technique used was simple random sampling. The number of farming families in Legon Kulon village is 1300 , then the research sample is taken as many as 60 wives from farming families.

\section{Measurement}

Primary data were collected directly using a structured questionnaire. For example, family characteristics (age, length of marriage, length of education, income, number of family members, and expenses), the data scale used for family characteristics is the ratio.

Gender relations are the division of labour between husband and wife related to domestic, public and social activities. The gender relations questionnaire with 28 statements was modified from Krzaklewska (2014) and Puspitawati (2012) used in this study; it consists of three dimensions: domestic, public, and social, the Cronbach's alpha 
value of 0.900. The questionnaire was measured using a 6-point Likert scale (1-6), namely 1 = husband only; $2=$ dominant husband; 3 = husband and wife are equal; $4=$ dominant wife; $5=$ Wife only; $6=$ Others.

The objective economic pressure is the problem of family finances by calculating the poverty rate and employment status. The objective economic pressure questionnaire was referenced and modified from the BPS Poverty Indicator, totalling 14 statements with a Cronbach's alpha value of 0.813 . The questionnaire was measured using a scale of $0-1$, namely $0=$ no; $1=$ yes. Subjective economic pressure is measured by looking at how the family's perceptions of the financial problems faced. The subjective economic stress questionnaire was referenced and modified from Hilton and Devall (1997), totalling 15 statements with Cronbach's alpha value of 0.966. The questionnaire was measured using a Likert scale (1-4), namely $1=$ never; $2=$ ever; $3=$ often; $4=$ always.

Family financial management uses and utilises money resources owned by the family in relation to planning, implementing, and evaluating activities. The financial management questionnaire was referenced and modified from Fitzsimmons et al. (1993), Firdaus and Sunarti (2009), Kumari (2011), consisting of three dimensions, namely financial planning, implementation, and evaluation, totalling 20 statements with Cronbach's alpha value of 0.873 . The questionnaire was measured using a Likert scale (1-4), namely $1=$ never; $2=$ ever; $3=$ often; $4=$ always.

Livelihood strategy is an effort made by a family to make a living to survive, which consists of engineering a livelihood, dual-income patterns, and spatial. The livelihood strategy questionnaire refers to the Scoones concept (1998), totalling 14 statements with Cronbach's alpha value of 0.616. The questionnaire was measured using a Likert scale (1-4), namely $1=$ never; $2=$ ever; $3=$ often; $4=$ always. The objective quality of life questionnaire measured by Lawton's (2001) approach amounted to 30 statement items with a Cronbach's alpha value of 0.883 .

Objective quality of life is life satisfaction regarding the home, the standard of living, income, health, work and personal environment and security. The objective quality of life questionnaire is measured using a scale of $0-1$, namely $0=$ no; $1=$ yes. Subjective quality of life is life satisfaction seen from the physical, economic, psychological and social aspects. The subjective quality of life questionnaire was modified from Puspitawati (2012); Zuliany (2013), totalling 28 statements with Cronbach's alpha value of 0.883 . Subjective quality of life questionnaires were measured using a Likert scale (1-4), namely $1=$ very dissatisfied; $2=$ not satisfied; $3=$ satisfied; 4 = very satisfied.

Furthermore, the variable will be given an assessment score on each questionnaire question. After that, the total score of each variable was transformed into an index to equalize the units so that the comparison of data categorization for each variable was uniform. The low, medium, and high categories were categorized based on the cut-off categorization by Sunarti et al. (2005), namely (00.0-60.0) categorized as low, (60.079.0) categorized as moderate, and (80.0-100.0) categorized as high.

\section{Analysis}

Data analysis using descriptive analysis and inferential analysis. Descriptive analysis (mean, minimum value, maximum value, and per centage) to identify farmer family characteristics, gender relations, economic pressures, family financial management, livelihood strategies and quality of life). 
PLS-SEM analysis was carried out to analyze the influence of gender relation variables, economic pressures, family financial management, livelihood strategies on the quality of life of farmer families. PLS was developed as a general method for estimating structural models that are measured indirectly by the manifest variable. PLS is a soft method because it does not require the assumption of the distribution of the observed variables, and the size does not have to be large (Chin, 2000).

The data used in the PLS test is to use the average result of the statement score from each dimension (Latan, 2013). The following steps were taken to create a complete model in data processing, namely: 1) developing a theory-based model; 2) development of flowcharts to show causality relationships; 3) conversion of flowcharts into a series of structural equations and measurement model specifications; 4) selection of input matrices and estimation techniques for the built model; 5) problem identification assessment; 6) evaluation of the model; and 7) model interpretation and modification.

\section{Findings}

\section{Family Characteristics}

Husbands and wives ranged in age from 18-70 years, with the average age of husband and wife in farmer families being husband 42.8 years and wife 39.1 years. More than half of the husband and wife in farming families (58.4\%) ranged in age 40-65 years. The majority of husbands and wives in farming families graduated from elementary school, with the per centage of husbands $(78.3 \%)$ and wives $(53.3 \%)$. If categorized based on the length of education taken by husband and wife, then all husband and wife couples $(100.0 \%)$ had less than nine years of education. Furthermore, the length of marriage between husband and wife ranged from 3-44 years, and the average length of marriage for the family was 19.7 years. The results showed that 3.3 per cent of families were categorized as large families, and a half $(50 \%)$ were small families with an average number of family members was four people. The average income per capita of a farming family is IDR 710,000.

\section{Gender Relations}

Based on the study results, it was shown that the farmer families who carried out the highest equal gender relations were in the social dimension, namely 21.7 per cent. This is reflected in the frequent involvement of husbands and wives in helping out with extended families and neighbours (50.0\%) and participating in community activities, such as the 17 August event (43.3\%).

Domestic dimension. The dominant thing done by the husband was planning for house repairs $(46.7 \%)$ and repairing the house when it was damaged $(56.7 \%)$, while the dominant thing done by the wife was planning and managing family finances and washing dishes. The public dimension, the dominant thing done by husbands is seeking work information to increase family income $(45.0 \%)$ and working to earn a living for more than 40 hours per week $(43.3 \%)$. The social dimension, the dominant thing done by the husband is cooperation/community service in the home environment (53.3\%), while the dominant thing done by the wife is helping out with extended family and neighbours (46.7\%). 
Based on the research results, gender relations in farmer families are in the dominant category of one party, which means that husband and wife work together but are still dominated by one of them. The dominant work done by husbands in farming families is planning house repairs, repairing houses when they are damaged and working to earn a living for more than 40 hours per week. The dominant jobs done by the wife in the farming family are raising children, washing clothes, washing dishes, planning and managing family finances.

Table 1. Distribution of the dimensions of the farmer family gender relations

\begin{tabular}{lccc}
\hline & \multicolumn{3}{c}{ Category (\%) } \\
\cline { 2 - 4 } Dimensions & $\begin{array}{c}\text { Low cooperation } \\
(<60)\end{array}$ & $\begin{array}{c}\text { Moderate } \\
\text { cooperation } \\
(60-79)\end{array}$ & $\begin{array}{c}\text { Balanced cooperation } \\
(>80)\end{array}$ \\
\hline Domestic & 40,0 & 48,3 & 11,7 \\
Public & 41,7 & 40,0 & 18,3 \\
Social & 33,3 & 45,0 & 21,7 \\
\hline Average & 38,3 & 44,4 & 17,2 \\
\hline
\end{tabular}

\section{Economic Pressure}

Objective Economic Pressure. The results showed that most of the farmer families (83.3\%) did not feel depressed about the objective economic conditions of the family. This is reflected in the source of home lighting that uses electricity (95\%), has good sanitation (toilet facilities in the house) (78.3\%), and the type of dwelling floor is ceramic (78.3\%). However, 6.7 per cent of farming families feel pressured by the objective economic conditions of the family. This is due to the inability of the family to buy clothes more than once a year $(83.3 \%)$, the failure of the family to meet the needs of animal protein (meat/chicken/milk) every week $(73.3 \%)$ and the education of the head of the household is still categorized as low (graduated from SD) (80.0\%). Based on the research results, it is known that the farming family can meet the minimum needs of the family, such as a proper place to live, the source of home lighting is electricity, the fuel for cooking is LPG.

Subjective Economic Pressure. The results showed that most of the farmer families $(90.0 \%)$ did not feel depressed about the subjective economic conditions of the family. This is reflected in the family never worrying about the child's disappointment when something the child wants has not been fulfilled $(71.7 \%)$, this is because the child does not force his wish on the parents, the family does not find it difficult to pay for electricity (85.0\%), families do not find it difficult to pay for children's education $(86.6 \%)$, and most families do not find it difficult to meet basic needs for clothing and food. Also, eight out of ten wives do not feel financial problems interfere with their relationships with other people. However, one in ten wives felt that the family expenditure was greater than the income and six out of ten wives felt that their family income was difficult to meet the current family needs.

Based on the results of the study, it is known that the farmer family feels happy with the subjective economic conditions of the family, such as the family does not find it difficult to meet the basic needs of the family. 


\section{Family Financial Management}

Based on the research results, it is known that most of the farmer family financial management is in a low category. This can be seen from the condition of the farmer family that has never written down the family's financial condition such as financial goals, income results, and daily or monthly expenses $(98.3 \%)$, and there is no routine and comprehensive evaluation of family expenses $(73,3 \%)$. Several things have been done by farming families related to financial management.

Planning Dimensions. Five out of ten families make a plan to spend money in one month, four out of ten families calculate the estimated daily cost of living and make plans to achieve the financial goals they want to achieve. Organizing Dimensions, setting the maximum cost standard in allocating expenses $(48.3 \%)$ and storing proof of payment for large purchases $(56.7 \%)$. Implementation Dimension, spending according to budgeted funds $(71.7 \%)$, buying something according to the previous plan $(83.3 \%)$ and trying to save (75.0\%). Evaluation Dimension, conducts regular expenditure evaluation (25.0\%), compares revenue and expenditure (31.7).

Table 2. Distribution of the dimensions of the farmer family financial management

\begin{tabular}{lccc}
\hline \multirow{2}{*}{ Dimensions } & \multicolumn{3}{c}{ Category $(\%)$} \\
\cline { 2 - 4 } & $\begin{array}{c}\text { Low } \\
(<60)\end{array}$ & $\begin{array}{c}\text { Medium } \\
(60-79)\end{array}$ & $\begin{array}{c}\text { High } \\
(>80)\end{array}$ \\
\hline Planning & 96.7 & 33.0 & 0.0 \\
Organizing & 100 & 0.0 & 0.0 \\
Implementation & 100 & 0.0 & 0.0 \\
Evaluation & 95.0 & 0.0 & 0.0 \\
\hline Average & 98.0 & 0.0 & 0.0 \\
\hline
\end{tabular}

\section{Livelihood Strategy}

Based on the results of the study, it can be seen that family farmers are still low in their income strategy efforts to increase the purchasing power of the family in all dimensions, namely the engineering of livelihoods (100\%), dual-income patterns $(96.6 \%)$ and immigration patterns $(98.3 \%)$. . The results showed that most of the farming families had never expanded their business (91.7\%), used modern technology (98.3\%), no family had more than one job $(80.0 \%)$, and there were no families who immigrated to other areas $(86.7 \%)$. Even though it is low, there are still families who are trying to make a living strategy.

In livelihood engineering, five out of ten families borrow venture capital to increase resource potential, such as wives selling food around the house, four out of ten people increase working hours to increase daily wages. The pattern of income is double, three out of ten families have had other/seasonal jobs, such as being a construction worker, and four out of ten families have family members who have worked. The pattern of immigration, four out of ten families have family members who have worked in other areas, and there are family members who work as migrant workers. 


\section{Quality of Life}

Objective Quality of Life. Based on the study results, it is known that more than half of the objective quality of life of farmer families in several dimensions is low. Farm families feel that the standard of living (100\%) of the family is relatively low, for example, the family cannot afford to buy clothes regularly (100\%), and the family cannot replace damaged household appliances (tables, chairs, beds) (66.7\%). However, in the dimensions of the family housing, this is indicated by homeownership (83.3\%), ownership of a bedroom that is separate from other rooms $(85.0 \%)$, a kitchen room that is separate from other rooms $(66.7 \%)$, and a floor area of more than $8 \mathrm{~m} 2$ for each occupant (71.7\%). Also, in terms of work, seven out of ten families have other/seasonal jobs. The results showed that farmer families still have an objective low quality of life, especially in terms of living standards, health and personal environment. This is supported by the low ability of the family to meet the needs for clothing, food, the ability to seek medical treatment and protect the environment around the house.

Table 3. Distribution of the dimensions of the objective quality of life of farmer families

\begin{tabular}{lccc}
\hline \multirow{2}{*}{ Dimensions } & \multicolumn{2}{c}{ Category $(\%)$} \\
\cline { 2 - 4 } & $\begin{array}{c}\text { Low } \\
(<60)\end{array}$ & $\begin{array}{c}\text { Medium } \\
(60-79)\end{array}$ & $\begin{array}{c}\text { High } \\
(>80)\end{array}$ \\
\hline Home & 35,0 & 5,0 & 60,0 \\
Standard of living & 100 & 0,0 & 0,0 \\
Income & 65,0 & 11,7 & 23,3 \\
Health & 81,7 & 18,3 & 0,0 \\
Job & 30,0 & 65,0 & 5,0 \\
Personal environment & 83,3 & 10,0 & 6,7 \\
\hline Average & 65,8 & 18,3 & 15,8 \\
\hline
\end{tabular}

Subjective Quality of Life. Based on the results of the study, it shows that the farmer family feels that they are of sufficient quality in the communication and physical dimensions. Statements that illustrate this are that the farmer family feels satisfied in terms of communication with their husbands $(83.3 \%)$, communication with children (70.0\%), communication with parents $(85.0 \%)$ and communication with in-laws (83, $3 \%)$ and feel satisfied in terms of husband's health (73.3\%), children's health $(66.7 \%)$, and families are satisfied with the state of family food $(86.7 \%)$. However, in other dimensions, the family feels disappointed with the subjective quality of life, namely in the economic and psychological dimensions

Table 4. The distribution of the subjective quality of life dimensions on a farmer family

\begin{tabular}{lccc}
\hline Dimensi & \multicolumn{3}{c}{ Category $(\%)$} \\
\cline { 2 - 4 } & $\begin{array}{c}\text { Low } \\
(<60)\end{array}$ & $\begin{array}{c}\text { Medium } \\
(60-79)\end{array}$ & $\begin{array}{c}\text { High } \\
(>80)\end{array}$ \\
\hline Physical & 28.3 & 60.0 & 11.7 \\
Economy & 81.7 & 18.3 & 0.0 \\
Psychological & 56.7 & 43.3 & 0.0 \\
Communication & 8.3 & 83.3 & 8.3 \\
\hline Average & 43.8 & 51.2 & 5.0 \\
\hline
\end{tabular}

Based on the study results, it is known that six out of ten families are very dissatisfied with their current financial situation, four out of ten families feel very dissatisfied with their current income. And three in ten families are dissatisfied with their children's academic achievement in school. 
The results showed that six out of ten farmer families felt that their lives were less qualified, especially in terms of financial conditions. Even so, the family still feels happy with the communication that exists between family members. Also, farmer families are satisfied with their homeownership and the ability to meet daily food needs.

\section{Factors Affecting Quality of Life}

The table explains that the influence between variables on farming families that has a direct and significant effect is the effect of economic pressure on livelihood strategies, the effect of gender relations on financial management, the influence of gender relations on livelihood strategies, the effect of financial management on quality of life and the effect of economic pressure on the quality of life. The analysis result of the variable model hypothesis testing on the quality of life in farmer families show the $\mathrm{R}$ Square number of 0.667 , which means that the model explains 66.7 per cent of the model variables affect the quality of life, and other variables outside of this study influence the remaining 33.3 per cent.

Table 5. Decomposition of the effects of influencing factors between variables on the farming family

\begin{tabular}{|c|c|c|c|c|c|c|c|}
\hline \multirow[t]{2}{*}{$\begin{array}{l}\text { Latent } \\
\text { Variable }\end{array}$} & \multirow[t]{2}{*}{$\begin{array}{l}\text { Total } \\
\text { effect }\end{array}$} & \multicolumn{5}{|l|}{$\begin{array}{l}\text { Indirect } \\
\text { effect }\end{array}$} & \multirow[t]{2}{*}{ Direct effect } \\
\hline & & QL & EP & FM & LS & GR & \\
\hline \multicolumn{8}{|l|}{$\overline{Q L}$} \\
\hline GR & 0.339 & & & 0.168 & & & 0.158 \\
\hline FM & 0.067 & & & & & & 0.067 \\
\hline LS & 0.238 & & & 0.128 & & & 0.110 \\
\hline EP & $0.213 *$ & & & 0.191 & 0.153 & 0.202 & $-0.759^{*}$ \\
\hline \multicolumn{8}{|l|}{ FM } \\
\hline GR & 0.156 & & & & & & 0.156 \\
\hline LS & $0.408^{*}$ & & & & & & $0,408^{*}$ \\
\hline EP & $-0.168 *$ & & & & 0.137 & 0.000 & $0.305^{*}$ \\
\hline \multicolumn{8}{|l|}{ GR } \\
\hline EP & 0.091 & & & & & & 0.091 \\
\hline \multicolumn{8}{|l|}{ LS } \\
\hline GR & $0.333^{*}$ & & & & & & $0.333 *$ \\
\hline EP & -0.479 & & & & & -0.200 & -0.279 \\
\hline
\end{tabular}

Note. QL: Quality of life; EP: Economic pressure; FM: Financial management;

LS: Livelihood strategy; GR: Gender relations 


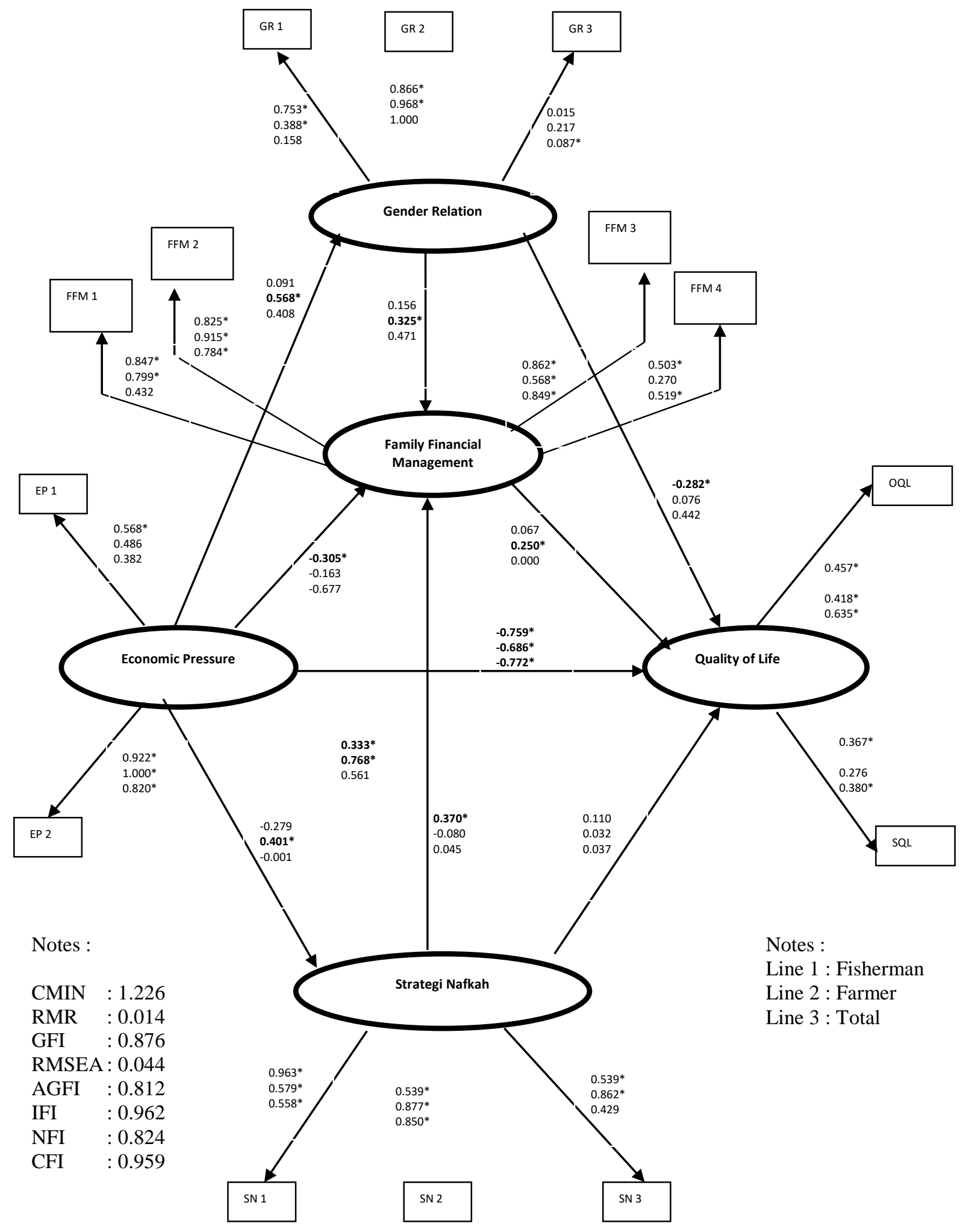

*) significant at $p$-value $<0.05$

Figure 1 SEM Measurement Model 


\section{Discussion}

The structural-functional theory approach is used in this study which views that a balanced division of roles and functions is the family's foundation in carrying out gender relations, financial management, and livelihood strategies to achieve the quality of life. The problem faced by most of the farming families in this study is the low level of education of the husband and wife (who have graduated from elementary school). According to Herawati, Ginting, Asngari. Susanto, and Puspitawati (2011), the low level of education of husband and wife will have implications for the type of work they have. The husband's type of work is farm labour, while most wives do not work (homemakers).

Gender relations in the farming family are in the dominant category of one party, which means that husband and wife work together but are still dominated by one of them. The dominant work done by husbands in farming families is planning house repairs, repairing houses when they are damaged and working to earn a living for more than 40 hours per week. The dominant jobs done by the wife in the farming family are raising children, washing clothes, washing dishes, planning and managing family finances. The results of this study are consistent with research by Puspitawati and Fahmi (2008); Simanjuntak et al. (2010); Karimah and Puspitawati (2020) stated that the role of the wife is more dominant in terms of domestic activities while the husband is more dominant in public activities. According to Puspitasari, Puspitawati, and Herawati (2013), gender relations are important to maintaining a balanced family function and dealing with economic pressures.

The results showed that family farmers in all dimensions of family financial management were categorized as low, this is reflected in the family never wrote down financial goals, did not record all income and did not write down family expenses. The results of this study are consistent with the research of Simanjuntak et al. (2010), which shows that low-income families do not carry out good financial management because the income they earn is irregular and quite minimal, so that there are no financial resources that can be appropriately managed. Low-income families undergo a process that is not based on written records of the things they plan to do but based on experiences and routines. Goldsmith (2010) states that good and effective financial management is an effort to fulfil the wants and needs of every family to achieve family goals.

In all dimensions, the subsistence strategy of the farmer family is low, this is reflected in the farmer family that does not expand the business, does not expand the land and does not increase the workforce. According to Frankenberger et al. (2002); Saragih et al. (2007), the livelihood strategy is an effort made by the family to meet their daily needs.

Economic pressures have a significant positive effect on livelihood strategies for farmer families. The more the family is economically depressed, the family livelihood strategy will increase. In this study, the dimensions of livelihood engineering and multiple income patterns can reflect livelihood strategies. This analysis is also supported by previous research conducted by Fofana (2009) that economic pressure encourages families to improve livelihood strategies, this is important so that families can survive in maintaining the sustainability of life. According to Scoones (1998) and Fofana (2009), economic pressures affect livelihood strategies, the greater the economic pressure on the family will increase the use of family capital. 
Thornton et al. (2007) stated that families with high economic pressure generally implement and plan economic coping strategies to increase income. Sabania and Hartoyo (2016) state that economic pressure affects the livelihood strategy, high economic pressure will make families adopt a double income pattern. According to Astuti et al. (2016), economic pressure affects family coping strategies related to efforts to increase income, economic pressure encourages families to have other jobs or provides opportunities for family members to meet family needs. Based on the research results, farmers' efforts to improve family livelihood strategies are by diversifying their sources of income, increasing working hours, having other jobs, and having family members who work as TKW / TKI.

Gender relations have a significant positive effect on financial management in farming families. The more responsive the family gender relations are, the more family financial management will be. In this study, the public dimension is better able to reflect gender relations. In accordance with the research of Kartikaningdyah, Ramdaniah and Mayasari (2013), respondents in this study have an open mind about the role of husband and wife in the family. Although the main task of the husband is to earn a living, the wife also plays a role in helping her husband to provide for the family income, and the respondent's family also plays a role in household financial arrangements. This proves that good gender relations between husband and wife will have an impact on good family financial management.

According to Herawati et al. (2011), gender relations directly and real influence the implementation of family financial management. The better the gender relations in terms of carrying out family duties both domestically and publicly, the equal husband and wife are, the better the quality of family financial management. Yohnson (2004) and Puspitawati (2012) that financial management is generally carried out by wives and an important part of the wife's role in the domestic sector. Gender relations affect financial management, families with high wives' education can carry out financial management well, because husbands give their wives a dominant role in making financial management decisions.

Gender relations have a significant positive effect on livelihood strategies for farmer families. The more responsive gender relations in the family are, the more livelihood strategies will be. According to Nugraheni (2012) and Puspitawati (2015), gender relations affect livelihood strategies, unfulfilled basic life needs encourage wives to try to meet these shortcomings by working, this makes wives have a dual role, namely roles in the domestic and public sectors. A wife who is involved in fulfilling family needs is one way of a livelihood strategy that utilizes human capital in the family, namely a double income pattern, to maintain harmonious relationships in the family, responsive gender relations are needed. Gender relations are related to the livelihood strategy, the livelihood strategy cannot be separated from the wife's involvement in working as an effort to increase family income.

Financial management has a positive and significant effect on the quality of life of farmer families. The better the family financial management, the better the quality of family life. The results of this study are consistent with previous research conducted by Fajrin (2011), and Grable Park, and Joo (2009) stated that the better the family's financial management, the more likely it is to improve the quality of life.

According to Parrota and Johnson (1998); Loilb and Hira (2005), everyone wants a good quality of life, while a good quality of life requires a healthy financial condition, to achieve a healthy condition, good management is needed. After the family 
carries out family financial management well, the family will feel satisfied with the family's financial condition. According to Rambe et al. (2008), Fajrin (2011), the level of education has an effect on financial management, the higher the education, the better the family's welfare, and the better the financial management, the higher the quality of family life (objective and subjective).

Economic pressures have a significant negative effect on the quality of life of farmer families. The more depressed the family is economically, the lower the quality of family life will be. The results of this study are consistent with previous research conducted by Simanjuntak (2010) that economic pressure is significantly negatively related to the quality of life, the lower the economic pressure, the higher the quality of life felt by the family. According to Firdaus and Sunarti (2009), the economic pressure felt by the family will shape the family's perception of aspects related to the quality of family life. Families who feel economic pressure will implement certain mechanisms by utilizing available resources to reduce this pressure to realise a better quality of life (family welfare). According to Hartoyo (2009), the high perceived economic pressure will increase the risk of insecurity in a family, especially in facing economic pressure and achieving prosperity. Economic pressure is significantly negatively related to the quality of life, the lower the economic pressure, the higher the quality of life felt by the family (Simanjuntak et al., 2010). The analysis results show that economic pressure has a significant negative effect on family welfare, family welfare decreases with increasing economic pressure (Sabania \& Hartoyo, 2016; Raharjo et al., 2015).

This study has several limitations that can be used as improvements for further research, namely (1) The research site was only conducted in Legon Kulon Village, Subang Regency, so that it could not describe the entire Subang Regency (2) Respondents who filled out the questionnaire were only wives so that this study only measures all variables based on the wife's/mother's perceived. In further research, it is better to involve husbands and children to describe the real family conditions. (3) The instrument uses closed questions, to obtain a more in-depth analysis, open questions should be used.

\section{Conclusion and Recommendation}

\section{Conclusion}

The farmer family is in the productive age (18-65 years), so that the potential to carry out economic activities is relatively high. Most husbands and wives' level of formal education in farming families is classified as low (graduating from elementary school). The average per capita income of a farming family is IDR 710000. The average size of more than half of the farming families is categorized as small family $(\leq 4$ people).

The results showed that economic pressure had a significant effect on gender relations, economic pressure had a significant effect on livelihood strategies, gender relations had a significant effect on financial management, gender relations had a significant effect on livelihood strategies, financial management had a significant effect on the quality of life, and economic pressure had a significant effect on the quality of life. 


\section{Recommendation}

Based on the results obtained from this study, the suggestion that can be given is those farmer families should further improve financial management and livelihood strategies by understanding the importance of utilizing limited family resources. Poor financial management and livelihood strategies for farmer families can be improved with extension assistance from NGOs or universities. The government or related agencies are expected to provide programs to improve the quality of life, such as forming MSMEs or cooperatives involving the wives of farmers and fishers. Future research may focus on variables that can affect the family quality of life, such as coping strategies.

\section{References}

Azalia, N. R. (2015). Pengaruh strategi nafkah rumah tangga petani padi sawah terhadap tingkat kesejahteraan. [skripsi]. Bogor: Institut Pertanian Bogor.

[BPS] Badan Pusat Statistik. (2014). Jumlah Penduduk Miskin Kabupaten Subang. Jakarta: Badan Pusat Statistik.

[BPS] Badan Pusat Statistik. (2016a). Penduduk 15 Tahun Ke Atas Menurut Status Pekerjaan Utama. Jakarta: Badan Pusat Statistik.

[BPS] Badan Pusat Statistik. (2016b). Jumlah Penduduk Miskin Jawa Barat. Jakarta: Badan Pusat Statistik.

Basrowi, \& Juariyah. (2010). Analisis kondisi sosial ekonomi dan tingkat pendidikan masyarakat desa srigading, kecamatan labuhan maringgai, Kabupaten Lampung Timur. Jurnal Ekonomi \& Pendidikan, 7(1), 1-2. doi: https://doi.org/10.21831/jep.v7i1.577.

Chambers, R. (1995). Poverty and livelihood: Whose reality counts. Environment and Urbanization, 7(1). doi: https://doi.org/10.1177/095624789500700106.

Fajrin, F. (2011). Manajemen keuangan dan kesejahteraan keluarga perempuan buruh pabrik di Kabupaten Bogor [skripsi]. Bogor: Institut Pertanian Bogor.

Firdaus, \& Sunarti, E. (2009). Hubungan antara tekanan ekonomi, manajemen keuangan, dan mekanisme koping dengan kesejahteraan keluarga wanita pemetik teh. Jurnal Ilmu Keluarga dan Konsumen, 2(1), 21-31. doi: http://dx.doi.org/10.24156/jikk.2009.2.1 .21.

Fitzsimmons, V. S., Hira, T. K., Bauer, J. W., \& Hafstrom, J. L. (1993). Financial management: development of scales. Journal of Family and Economic Issues, 14(3), 257-274. ISSN: 1058-0476.

Fofana. (2009). A socio-economic sustainability assessment of livelihoods from scrap metal collection in Freetown, Sierra Leone [tesis]. Lund University International Master's Programme in Environmental Studies and Sustainability Science.

Frankenberger, T. R, Luther, K., Becht, J., \& Katherine. (2002). Household Livelihood Security Assessments: a toolkit for practitioners. Tucson: Tango International, Inc.

Garman, E. T., \& Forgue, R. E. (2000). Personal Finance, Sixth Edition. Boston: Houghton Mifflin Publishing.

Goldsmith, E. B. (2010). Resource Management for Individuals and Families. 4th ed. New Jersey: Pearson Education. 
Grable, J. E., Park, J. Y., \& Joo, S. H. (2009). Explaining financial management behaviour for Koreans living in the United States. Journal of Consumer Affairs, 43(1), 80-105. doi: http://doi.org/10.1111/j.1745- 6606.2008.01128.x.

Herawati, T., Ginting, B., Asngari. P. S., Susanto, D., \& Puspitawati, H. (2011). Ketahanan pangan keluarga peserta program pemberdayaan masyarakat di pedesaan. Jurnal Gizi dan Pangan, 6(3), 208-216. doi: http://dx.doi.org/10.25182/jgp.2011.6.3.208-216.

Hilton, \& Devall. (1997). The Family economic strain scale: development and evaluation of the instrument with single and two parents. Journal of Family and Economic Issues, 18(3), 248-271. ISSN: 1058-0476

Karimah, R. A., \& Puspitawati, H. (2020). The Influence of Gender Roles and Coping Strategies to The Fishermen's Family Happiness Index. Journal of Family Sciences, 5(1), 1-19. doi: https://doi.org/10.29244/jfs.5.1.1-19

Kartikaningdyah, E., Ramdaniah, C., \& Mayasari, M. (2013). Kontribusi Wanita Nelayan Dalam Sosiokultural Gender di Kelurahan Pulau Panjang BarelangBatam. Jurnal Akuntansi, Ekonomi dan Manajemen Bisnis, 1(1), 88-94. doi: https://doi.org/10.30871/jaemb.v1i1.201

Khizindar, T. M. (2009). Quality of life in developing countries: An empirical investigation. Journal of American Academy of Business, 14(2), 162-170. ISSN: 1540-7780.

Kumari, K. K. (2011). Marital adjustment and family resource management of working women among different income groups. International Referred Research Journal, 3(27), 37-39. ISSN: 2278-4497.

Lawton, P. W. (2001). Quality of life and the end of life. Di dalam : Birren JE dan Schaie KW, editor. London: Academic Pr.

Loibl, C., \& Hira, T. K. (2005). Self-directed financial learning and financial satisfaction. Journal Financial Counseling and Planning, 16(1), 11-21.

Megawangi, R. (2014). Membiarkan Berbeda: Sudut Pandang Baru tentang Relasi Gender. Depok (ID): Indonesia Heritage Foundation.

Muflikhati, I., Hartoyo., Sumarwan, U., Fahrudin, A., \& Puspitawati, H. (2010). Kondisi sosial ekonomi dan tingkat kesejahteraan keluarga: kasus di wilayah pesisir Jawa Barat. Jurnal Ilmu Keluarga dan Konsumen, 3(1), 1-10, doi: http://dx.doi.org/10.24156/jikk.2010.3.1.1

Nugraheni, W. (2012). Peran dan potensi wanita dalam pemenuhan kebutuhan ekonomi keluarga nelayan. Journal of Educational Social Studies, 1(2), 104- 111. P-ISSN: 2252-6390, E-ISSN: 2502-4442.

Okech. (2012). Effect of economic pressure on resilience and strengths of individuals living in extreme poverty. Journal of Poverty, 16, 429-446. ISSN : 1087-5549.

Parotta, J. L., Johnson, P. J. (1998). The impact of financial attitudes and knowledge on financial management and satisfaction of recently married individuals. Journal Financial Counseling and Planning, 9(2).

Puspitasari, N., Puspitawati, H., \& Herawati, T. (2013). Peran gender, kontribusi ekonomi perempuan, dan kesejahteraan keluarga petani hortikultura. Jurnal Ilmu Keluarga \& $\quad$ Konsumen, 6(1), 10-19. doi: https://doi.org/10.24156/jikk.2013.6.1.10

Puspitawati, H. (2012). Gender dan Keluarga: Konsep dan Realita di Indonesia. Bogor: IPB Press. 
Puspitawati, H. (2015). Pentingnya pendidikan keluarga berwawasan gender bagi Indonesia [kajian akademik]. Departemen Ilmu Keluarga dan Konsumen.

Raharjo, I. T., Puspitawati, H., \& Krisnatuti, D. (2015). Tekanan ekonomi, manajemen keuangan, dan kesejahteraan pada keluarga muda. Jurnal Ilmu Keluarga dan Konsumen, 8(1), 38-48. doi: http://dx.doi.org/10.24156/jikk.2015.8.1.3 8.

Rambe, A., Hartoyo, \& Karsin, E. S. (2008). Analisis alokasi pengeluaran dan tingkat kesejahteraan keluarga: Studi di Kecamatan Medan Kota, Sumatera Utara). Jurnal Ilmu Keluarga dan Konsumen, 1(1), 16-28.

Rodhiyah. (2012). Manajemen keuangan keluarga guna menuju keluarga sejahtera. Topik Utama, 28-33. ISSN: 0126-0731

Sabarella., Komalasari, W., Respati, E., Noviati., Wahyuningsih, S., Ningrum, M. H., \& Sehusman. (2014). Analisis Kesejahteraan Petani. Jakarta: Pusat Data dan Sistem Informasi Pertanian Kementan.

Sabania, H., \& Hartoyo. (2016). Economic pressure, livelihood strategies, and family well-being in Cimanuk watershed, Garut and Indramayu, West Java, Indonesia. Journal of Family Sciences, 1(1), 24-38. doi: https://doi.org/10.29244/jfs.1.1.2438

Scoones, I. (1998). Sustainable rural livelihoods: a framework for analysis. IDS Working Paper 72, 1-23

Soesilo. (2007). Penyebab kemiskinan masyarakat tani (Studi Di Dusun Ngebrong, Desa Tawangsari, Kecamatan Pujon, Kabupaten Malang). Journal of Indonesian Applied Economics, 1(1), 57-6.

Sunarti, E., Tati, Atat, S. N., Noorhaisma, \& Lembayung, D. P. (2005). Pengaruh tekanan ekonomi keluarga, dukungan sosial, kualitas perkawinan, pengasuhan dan kecerdasan emosi anak terhadap prestasi belajar anak. Media Gizi dan Keluarga, 29(1), 34-40. ISSN 02116-9363.

Sunarti, E., Kholifah, I., Vidiastuti, F., Kharisma, N., Rochimah, N., \& Herawati, T. (2013). Family vulnerability, family resource management, and family strength of aging family members. Paper presented at 5th International Work and Family Conference, University of Sydney, July 17-19.

Sunarti, E., Sumarno, H., Murdiyanto, \& Hadianto, A. (2009). Indikator kerentanan keluarga petani dan nelayan. Institut Pertanian Bogor.

Thronton, P. K., Boone, R. B., Galvin, K. A., Burnsilver, S. B., Walthaka, M. M., Kuyiah, J., Karanja, S., Estrada, E.G., \& Herrero, M. (2007). Coping strategies in livestock dependent household in East and South Africa: a synthesis of four case studies. Springer Science and Business Media, LLC, 35(1), 461-476.

Van Raaij, W. F., Antonides, G., \& De Groot, I. M. (2020). The benefits of joint and separate financial management of couples. Journal of Economic Psychology, 80. doi: https://doi.org/10.1016/j.joep.2020.102313

Yohnson. (2004). Peran universitas di Surabaya dalam meningkatkan jumlah keluarga mapan di Surabaya. Jurnal Manajemen dan Kewirausahaan, 6(1), 54-71.

Zuliany. (2013). Peran istri dalam pengelolaan sumber daya keluarga dan kesejahteraan subyektif keluarga pada sistem matrilineal [skripsi]. Bogor: Institut Pertanian Bogor. 